\title{
Marcello Malpighi (1628-1694), Founder of Microanatomy
}

\author{
Marcello Malpighi (1628-1694), Fundador de la Microanatomía
}

Rafael Romero Reverón

ROMERO, R. R. Marcello Malpighi (1628-1694), founder of microanatomy. Int. J. Morphol., 29(2):399-402, 2011.

SUMMARY: Marcello Malpighi, (1628-1694), Italian physician, anatomist, botanist, histologist and biologist developed methods to study living things by using the newly invented microscope to make a number of important discoveries about living tissue and structures, and initiated the science of microscopic anatomy. For almost 40 years he used the microscope to describe major types of plant and animal structures and, in doing so, discovered major areas of research in botany, embryology, human anatomy and pathology for future generations of biologists. He provided anatomical basis for eventual understanding of human physiological exchanges. Marcello Malpighi was the founder of microanatomy. Many microscopic anatomical structures are named after him: the basal layer, renal corpuscles, as well as insect excretory organs.

KEY WORDS: Marcello Malpighi; Microscopic anatomy; Microscope; Histology.

Marcello Malpighi (1628-1694), Italian physician, anatomist, botanist, histologist and biologist, in the seventeenth century developed several methods to study living organisms using the newly invented microscope. This allowed him to make a number of important discoveries about live tissue and structures and to set fundamentals of new science of microscopic anatomy. In his honor, various microscopic anatomical structures bear his name: The basal layer, the corpuscles in kidneys and spleen, and the excretory system of insects (Firkin \& Whitworth, 1990). He was also the most exhaustive botanist of the time. As Aggregate Professor of the Department of Human Anatomy at Vargas Medical School, Central University of Venezuela and member of the Venezuelan Society of History of Medicine, research and compilation of information available to realize this brief biographical synthesis of some aspects of interest in the life and works of Marcello Malpighi was carried out in the present study. This study is part of an ongoing line of investigation on people who have realized significant contributions in education and learning of anatomy, as complementary knowledge in the study of human anatomy.

Malpighi was born at Crevalcore, just outside Bologna, Italy, in March 10, 1628. The son of small landowners, he was raised on the farm his parents owned. His father had him engage in grammatical studies at an early

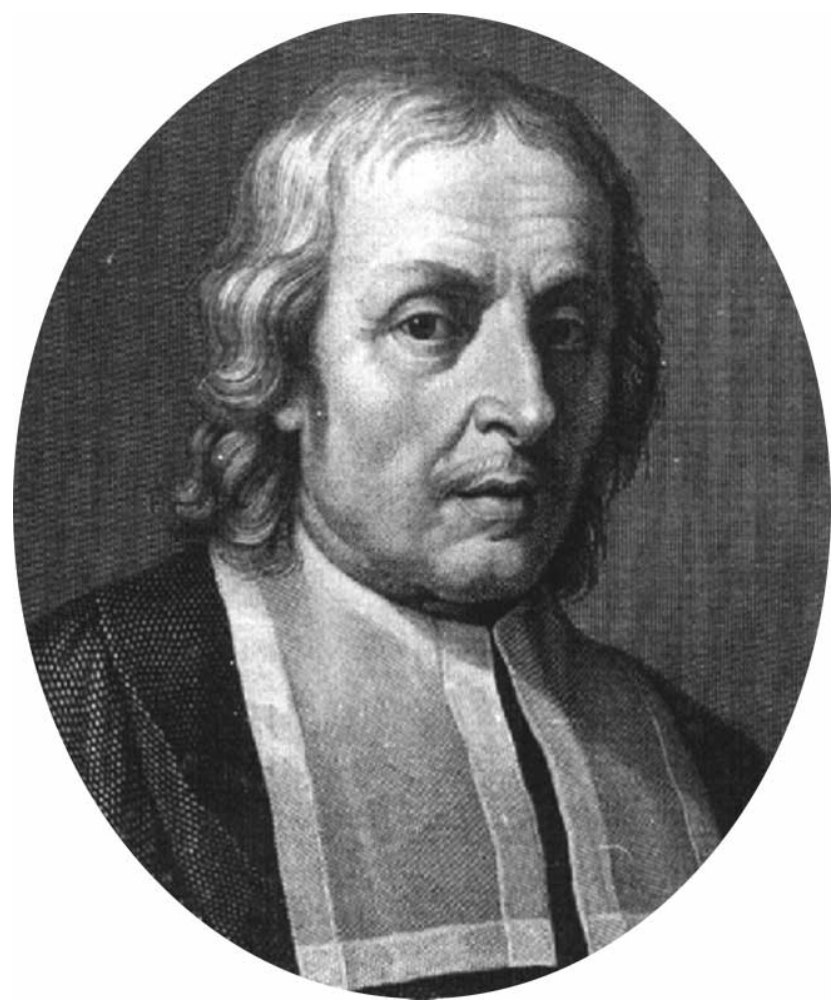

Fig. 1. Marcello Malpighi (1628-1694), Founder of Microanatomy. http://www.disri.unibo.it/NR/rdonlyres/1FE6B3D4-92EB-41D5B6BD37267885B767/55906/malpighiovale.png 
age. In 1646 he entered the University of Bologna to study medicine and philosophy. He suffered the loss of both parents and his paternal grandfather died when he was 21 years old.

This event forced him to temporarily abandon his studies in order to take care of his eight brothers and sisters and settle his family affairs. Two years later he resumed his studies obtaining doctorates in both medicine and philosophy in 1653 despite opposition from university authorities because he was not Bolognese by birth (Hooper et al., 2006). He was subsequently appointed as a teacher and immediately dedicated himself to further study anatomy and medicine (García, 1987). While at Bologna, Malpighi was part of a small anatomical society headed by his anatomy professor the teacher Bartolomeo Massari, in whose home the group met to conduct dissections and vivisections of animals. Malpighi later married Massari's daugther. The marriage was short lived, Francesca Massari died the following year. Malpighi's independence of thought and his refusal to follow Galen, aroused opposition. Still, he was offered in 1656 a chair of medical practice at the university, two years after graduating in medicine and philosophy and one year after

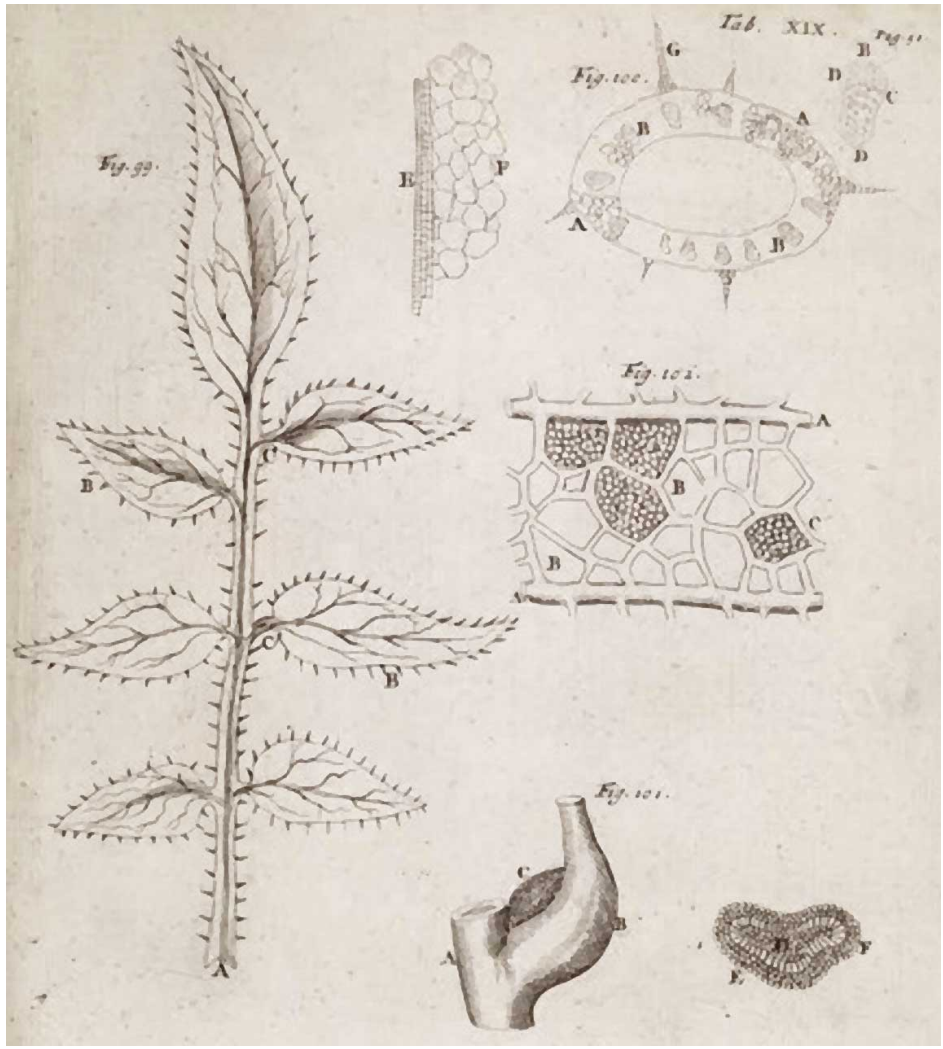

Fig. 2. Illustration from Marcelli Malpigh. Opera omnia, seu, Thesaurus locupletissimus: viginti quator tractatus complectens et in duos tomos distributus, quorum tractatum seriem videre est dedicatione absoluta. Lugduni Batavorum : Apud Petrum vander Aa, 1687. http://www.botanicus.org/ title/b1208119x the death of his teacher (and father-in-law) Massari (Porter, 2004). Later that year, the Archduke Leopold of Tuscany invited Malpighi to teach and hold a special chair of theoretical medicine created for him at the recently established University of Pisa.

There, he became a member of the Cimento Academy, one of first scientific societies, a group that saw itself as heirs of Galilean science in Italy and which included many famous scholars. Malpighi was particularly close to Giovanni Alfonso Borelli, mathematician and naturalist, who was a prominent supporter of Accademia del Cimento, who introduced him to iatromechanics (human body like a set of different machines). This new study attempted to apply Descartes' philosophy of mechanics to living bodies and consequently to consider animals as complex mechanical beings. Within the circle of Academy, Malpighi was also introduced to a very important instrument in his life: the microscope. Malpighi questioned prevailing medical teachings at Pisa, tried experiments on color changes in blood, and attempted to recast anatomical, physiological and medical problems of the day (Zúñiga, 1977).

In 1659, after three years work at Pisa, he returned to Bologna where he continued to teach and do research with his microscope. Not only did Malpighi prove himself a follower of the philosophy of mechanics and a master of the microscope, but he also managed by means of various anatomical stratagems to penetrate internal structures and reveal subtle mechanism of how they worked (Mandrioli \& Ariatti, 1991). Malpighi's views induced increasing controversy and dissent, mainly from envy, jealousy, and lack of understanding on the part of his colleagues.

In 1661 he identified and described the pulmonary and capillary network connecting small arteries with small veins, one of the major discoveries in the history of science (Adler, 2004). Microscopically examining a frog's lungs, he was able for the first time to describe the lung's structure accurately as thin air spaces surrounded by a network of tiny blood vessels. This explained how air (oxygen) is able to diffuse into blood vessels, a key to understanding process of respiration. It also provided the one missing piece of evidence to confirm William Harvey's revolutionary theory of blood circulation. Malpighi had discovered the capillaries, the microscopic connecting link between the veins and arteries (Lyons \& Petrucelli, 1994). Two years later in 1663, Malpighi was called to accept a professorship in medicine at the University 
of Messina in Sicily. He remained there for four years. Malpighi pursued his microscopic studies while teaching and practicing medicine in Messina. In short, Malpighi continued his work directed at revealing microscopic structure of living beings (Nuland, 2008).

He studied chick embryo development and made detailed drawings. He identified taste buds on the human tongue and regarded them as nerve endings, and described several minute structures of brain, optic nerve, and fat reservoirs. In 1665 he published three papers: De Lingua, about the sense of taste; De Cerebro, about the workings of the brain, where he concluded that this organ is a gland (in terms of modern endocrinology this deduction is correct because neurotransmitter substances represent paracrine hormones, and hypothalamus of the brain has long been recognized for its hormone-secreting capacity) and De Externo Tactus Organo, about the sense of touch. In his paper "De Polypo Cordis" in 1666, he was the first to see the red blood cells under a microscope and to attribute the color of blood to them (Puigbò, 2002). Malpighi described how form of a blood clot differed in right versus left side of the heart. He identified rete mucosum. He established that nerves and spinal column both consisted of bundles of fibers. Malpighi clearly described the structure of the kidney and suggested its function as a urine producer. He identified spleen as an organ, not a gland; structures in both kidney and spleen are named after him.

He demonstrated that bile is secreted by the liver, not the gall bladder. In showing bile to be uniform in color, Marcello Malpighi disproved a 2,000 year old idea that bile was yellow or black. The first good comparative study of liver from snails through fishes, reptiles, and mammals up to man, is due to Malpighi. He was also among first to study human fingerprints. Another success for iatromechanics came with the publication of De Viscerum Structura, in which Malpighi showed evidence of complex system of follicles, tubules and vessels in kidneys and developed a new model of the secretion process. In 1667, Malpighi returned to Bologna and during his medical practice, he studied microscopic subdivisions of specific living organs, such as liver, brain, spleen, kidneys, and bones and deeper layers of skin that now bear his name. Impressed by minute structures he observed under the microscope, he concluded that most living materials are glandular in organization and that even the largest organs are composed of minute glands, and that these glands exist solely for separation or for mixture of juices (Motta, 1998). Marcello Malpighi started a collaboration with the Royal Society of London who designated him as an honorary member, the first time such recognition was given to an Italian. From then on, all his works were published in
London, Great Britain. Malpighi conducted many studies on insect larvae establishing basis for their future study. In 1669 he studied structure and development of the silkworm which is regarded as his most important work in this area. In his historic work in 1673 on chick embryology, he discovered aortic arches, neural folds, and somites. He generally followed William Harvey's views on development (Ackerknecht, 1982), though Malpighi probably concluded that embryo is preformed in egg after fertilization. Although he remained faithful to microscope and iatromechanics, he further extended his field of research: to insects (1669: De Bombyce), to embryology (1673: De formatione pulli in ovo) and to plants (1675-1679: Anatomes plantarum). In addition to his anatomical studies, he was one of rare contemporary scholars who studied plants; he published his findings in a book Anatomia Plantarum in 1671. It was the most exhaustive study of botany at the time, published by the Royal Society (Papp \& Agüero, 1994). Malpighi's work on plants was honored by great Swedish botanist Linnaeus, who named the genus Malpighia and type genus Malpighiaceae in his honor, a family of tropical and subtropical flowering plants. In 1686-87 the Royal Society of London published Malpighi's Opera omnia, increasing his fame to an international level (Doscher, 2005).

In 1691 Pietro Antonio Pignatelli, a Catholic Cardinal linked to Bologna, who had been his personal friend, was elected Pope Innocent XII. He invited Malpighi to become his personal physician or archiater. Malpighi attempted to refuse this honorable nomination, but his friend succeeded. He was nominated "cameriere segreto partecipante", a title which was equivalent of clerical status of Monsignor and was received in Rome with highest honors. He was elected to the College of Doctors of Medicine, his name was placed in Roman Patriciate Roll, and he was given title of honorary valet. Nonetheless, Malpighi lived through this forced transfer with bitterness and sadness. During this time he taught medicine in the Papal Medical School and wrote a long treatise about his studies which he donated to the Royal Society of London. Three years later, on November 19, 1694, Marcello Malpighi died of an apoplectic fit at the age of sixty-seven.

In 1697, three years after his death, his Opera posthuma was published by the Royal Society of London. Malpighi may be regarded as the first histologist. For almost 40 years he used microscope to describe major types of plant and animal structures and, in doing so, uncovered major areas of research in botany, embryology, human anatomy and pathology for future generations of biologists. Malpighi extended use of microscope to intricate organization of living things, heretofore, unimagined levels below that of unaided sight. Moreover, his lifework brought into question 
prevailing concepts of body function (Encyclopaedia Britannica, 2009). Although Malpighi could not imagine what new remedies might come from his discoveries, he was convinced that microscopic anatomy by showing minute construction of living things, would start an era of changes in the field of medicine. Marcello Malpighi was the founder of microanatomy. He in fact, provided the anatomical basis for eventual understanding of human physiology exchanges.

ROMERO, R. R. Marcello Malpighi (1628-1694), fundador de la microanatomía. Int. J. Morphol., 29(2):399-402, 2011.

RESUMEN: Marcelo Malpighi, (1628-1694), médico italiano, anatomista, botánico, histólogo y biólogo, usando el microscopio, recientemente inventado en esa época, desarrolló métodos para estudiar organismos vivos, con lo cual contribuyo al inicio del desarrollo de la ciencia de la anatomía microscópica. Por casi 40 años Malpighi utilizó el microscopio para describir los tipos principales de estructuras de algunas plantas y animales, facilitando el inicio de campos de investigación importantes en botánica, embriología, anatomía humana y patología. Marcelo Malpighi fue fundador de la anatomía microscópica. Muchas estructuras anatómicas microscópicas se nombran en su honor, como; la capa de Malpighi, los corpúsculos renales, así como los túbulos renales.

PALABRAS CLAVES: Marcelo Malpighi; Anatomía microscópica; Microscopio; Histología.

\section{REFERENCES}

Ackerknecht, E. H. A Short History of Medicine. Baltimore. The Johns Hopkins University Press, 1982. p.p. $115,118,126$.

Adler, R. E. Medical Firsts from Hippocrates to the Human Genome. Hoboken, John Wiley \& Son, Inc., 2004. p.73.

Doscher, A., 2005. Marcello Malphighi. Disponible en: http:/ /www.scienzagiovane.unibo.it/english/scientists/ malpighi-1.html

Encyclopaedia Britannica. Marcello Malphighi. 2009.http:/ /www.britannica.com/EBchecked/topic/360486/ Marcello-

Firkin, B. G. \& Whitworth J. A. Dictionary of Medical Eponyms. Park Ridge, New Jersey, The Parthenon Publishing Group, Inc., 1990. p.330.

García, A. Historia de la Medicina. Buenos Aires. Interamerican-Mc Graw-Hill, 1987. pp.188-98.

Hooper A.; Gottlieb, H.; Bowers, B. \& Bowers, B. 1,000 Years, 1,000 People. Ranking The Men and Women who shaped the millennium. New York, Fall River Press., 2006. pp. 264.

Lyons, A. \& Petrucelli, J. History of Medicine. Spanish edition. México, Mosby/Doyma Libros, 1994. p.434.

Mandrioli, P. \& Ariatti, A. Marcello Malpighi, pioneer of the experimental research in biology. Aerobiologia, 7:39, 1991.
Motta, P. Marcello Malphighi and the foundations of Functional Microanatomy. Anat. Rec., 253(1):10-2, 1998.

Nuland, S. Doctors The Ilustrated History of Medical Pioneers. New York, Black Dog \& Leventhal Publishers Inc., 2008. p.p.131, 333.

Puigbò, J. La Fraga de la medicina clínica y de la cardiología. Caracas, Universidad Central de Venezuela. Consejo de Desarrollo Científico y Humanístico, 2002. p.p.260-5.

Papp, D. \& Agüero, A. Breve Historia de la Medicina. Buenos Aires, Claridad, 1994. p.p.175-6.

Porter, R. A Short History of Medicine. Spanish edition. México, Santillana Ediciones Generales, 2004. p. 113.

Zúñiga, M. Historia de la Medicina. Caracas, Edime, 1977. p.p. $259-60$.

Dirección para correspondencia:

Dr. Rafael Romero Reverón.

Cátedra de Anatomía Normal

Escuela de Medicina J.M. Vargas

Facultad de Medicina

Universidad Central de Venezuela

VENEZUELA

Email: romeroreveron@cantv.net,rafa1636@yahoo.es

Recibido : 10-08-2010

Aceptado: 25-04-2011 